\title{
The emergence of ringing vertigo
}

\author{
Trevor Jackson \\ Reports from bell ringers show how increased awareness can lead to the creation of a new condition
}

BMJ, London WC1H 9JR

Trevor Jackson assistant editor tjackson@bmj.com

BMJ 2005;331:1502-3

\begin{abstract}
Ding dong merrily on high, goes the famous Christmas carol, but for some of the United Kingdom's 40000 campanologists the bells have not been ringing so merrily. Instead, church bell ringers have this year been complaining of a disorder that has been forcing them to abandon their towers and steeples and seek out hypnotherapists and counsellors in search of a cure. Symptoms include vertigo, a sensation of the world caving in, anxiety, and a loss of feeling in the hands and feet. In some cases these have been so severe that ringers have taken to their beds. "I was unable to do anything for more than a week, apart from lie in bed with my eyes shut," said one campanologist.
\end{abstract}

Reports of the condition first surfaced earlier this year in the letters pages of the Ringing World, the official weekly journal of the Central Council of Church Bell Ringers. The Ringing World more usually carries news of church restorations, peal reports, and details of various campanological festivals and meetings, but from May it began to attract a series of self submitted clinical case studies. The first came in a letter from Julie Mottershead of Ashtead, Surrey, who coined the term "ringing vertigo" by which the condition has since been known. ${ }^{1}$ She said, "I found that over a few sessions I was feeling increasingly uncomfortable ringing up [using an increasing angle of swing to turn the bells through nearly $180^{\circ}$ to the ringing position], and then suddenly I could not ring at all-it was as if the world was caving in around me. This was all the more surprising as I am not in the least a 'nervy' person.

"I went to my GP who prescribed anti-anxiety medication. And it worked-but I fear the effect is starting to wear off. I can still ring, but the fear that the 'cave in' will occur is still there-and this in itself makes me anxious."

Ms Mottershead asked if any readers of the Ringing World were doctors, hypnotherapists, or practitioners

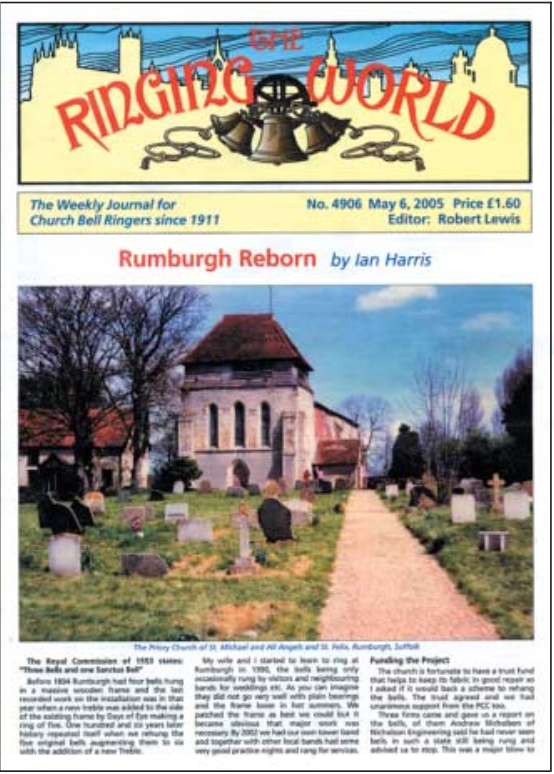

Ringing World, where the first report appeared of cognitive behavioural therapy, explaining, "It would be lovely to get some advice on how to proceed from someone who is familiar both with these symptoms and with ringing." Her appeal triggered off months of correspondence from other affected ringers, psychiatrists, and counsellors. One bell ringer, quoting from the Diagnostic and Statistical Manual of Mental Disorders, described Ms Mottershead's experiences as a panic attack, for which bell ringing provided numerous potential triggers: "It may be a fear of heights or of falling through the floor, of falling off a box, or a bell falling on you or a rope catching round your neck, of being unable to escape from the tower if there's a fire."'

\section{A question of balance}

Another person with the condition, however, was sceptical about panic as the cause of ringing vertigo. She wrote, "I think that there is a connection between the sound and vibrations of the bells and the balance mechanism of the ears. This is made worse if the tower sways when the bells are rung." She added, "I haven't found a complete cure for this complaint yet, but I'm looking for one. I think that anti-panic drugs would make things worse!"

Perhaps the most vivid account of ringing vertigo came a month later, from Rosemary Bennett of Bournemouth, Hampshire, who said she had been so frightened by her experience that she had not been able to return to her hobby. She said, "I experienced what I can only describe as a huge flash of light causing me to feel very lightheaded, slight loss of feeling in my hands and the very worst uncontrollable shaking of both legs and feet. Whilst somehow still in control of my bell I felt I was either about to have a stroke or a heart attack and would collapse."

After a second experience, Ms Bennett went to her general practitioner and was prescribed prochlorperazine "with no effect." She eventually saw an ear, nose, and throat consultant who instigated balance tests, hearing tests, and magnetic resonance imaging. When everything drew a blank he referred her to a neurologist, who immediately diagnosed "panic disorder" and prescribed antidepressants and sent her on an anxiety course. None of these things worked.

A different general practitioner, however, told Ms Bennett her symptoms sounded similar to those of stage fright or performance anxiety, and she searched on the internet to find out more. "My experiences were there in black and white: light-headedness, palpitation, huge adrenalin surge and uncontrollable body tremor. I felt slightly jubilant that this might actually prove that there was something physically wrong with me and it was not all in the mind (like I am sure some people will still believe)."

In early July the ringing vertigo letters received publicity in the news pages of the Guardian and Times newspapers, which in turn attracted further letters to the Ringing World. One ringer wrote, "Since July 2004 I have been unable to ring at all due to the symptoms described in the article." ${ }^{, 5} \mathrm{He}$ described an attack in which "suddenly it was like the whole tower was swaying and I couldn't get my balance." He said he had no fear of the tower itself, "yet put a rope in my hand and start me ringing and I feel like I'm going to topple over."

Oxford based psychiatrist Richard Mayou, who had been following the correspondence in his wife's copies of the journal, wrote, "Two of your correspondents give very clear accounts of phobic anxiety with panic, similar to much more common fears of spiders, mice, snakes, 
heights and many other situations. Such phobias are largely unrelated to more generalised anxiousness. There are some common features with the shakiness and lack of confidence that often afflicts musicians and other performers." ${ }^{\circ} \mathrm{He}$ said anti-anxiety drugs could have some benefit adding, "The very well proven treatment for phobic anxiety is cognitive behavioural treatment usually supervised by a psychologist."

\section{Early evidence}

Three hundred and forty years earlier another bell ringer described his fear that the bell or the church tower would fall on top of him. John Bunyan wrote: "I began to think how if one of the Bells should fall ... but then it came into my head, how if the Steeple itself should fall, and this

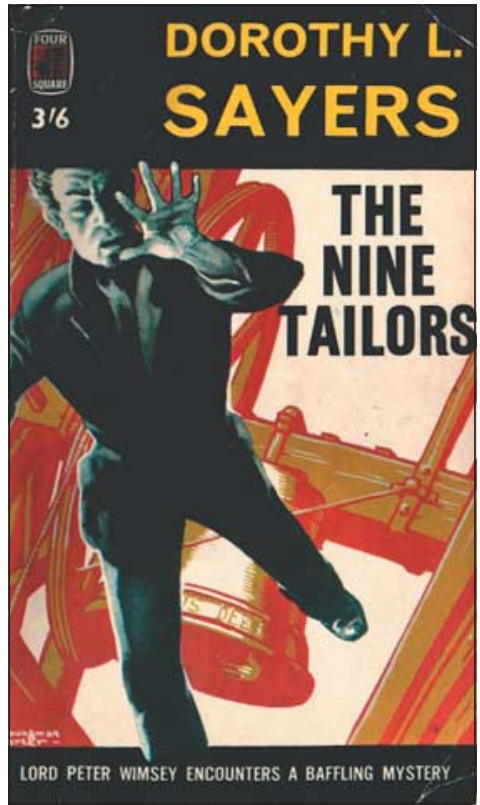

writer Dorothy L Sayers's "graphic detail of the vibration and deafening sound" of bell ringing in her 1934 novel The Nine Tailors.

While it would be lovely to let Bunyan or Sayers have the last word on ringing vertigo, perhaps the best epilogue comes from a letter in Ringing World this month. ${ }^{9}$ An affected ringer from Petworth in West Sussex wrote to say that the night after seeing a specialist for treatment of an unrelated condition, she gradually realised that she was not experiencing any of the usual vertigo symptoms. "It was the same for Sunday ringing, and subsequently six weddings." She wrote, "I took no pills and the treatment involved very gentle muscle manipulation." What was the unrelated complaint? "The dreaded hot flushes. I haven't had any of those either!"

thought, (it may fall for ought I know) would, when I stood and looked on, continually so shake my mind, that I durst not stand at the Steeple door any longer, but was forced to fly for fear it should fall upon my head." Bunyan's experience at Elstow church was cited this year as evidence that ringing vertigo was not new; it had just not been properly discussed before, Ringing World editor Robert Lewis told the Guardian, "perhaps because the sufferers feared they might be ridiculed."

The Times devoted a leading article to ringing vertigo, calling for "more enthusiastic support for our campanologists so that aspirants are everywhere queuing to work with Quasimodo" and citing the crime
And so ringing vertigo vanished, almost as unexpectedly as it had first arisen in the pages of Ringing World seven months earlier.

Competing interests: None declared.

1 Mottershead J. Ringing vertigo. Ringing World 2005 May 6:426.

Camp J. Ringing vertigo. Ringing World 2005 May 20:473.

Sherlaw-Johnson R. Ringing vertigo-another angle. Ringing World 2005 June 10:548.

Bennett R. Ringing vertigo. Ringing World 2005 July 1:618.

Wild J. A young sufferer. Ringing World 2005 July 29:717.

Wild J. A young sufferer. Ringing World 2005 July 29:717.
Mayou R. "Ringing vertigo." Ringing World 2005 July 15:666.

Mayou R. "Ringing vertigo." Ringing World 2005 July 15:666.
Bunyan J. Grace abounding to the chief of sinners. New York: Oxford Univer-

Morris M. Church ringers suffer spate of panic attacks. Guardian $2005 \mathrm{Jul} 4$. 9 Major H. Vertigone! Ringing World 2005 Dec 2:1162. Bunyan J. Grace abou
sity Press Inc, 1998.

\title{
Barbering in mice: a model for trichotillomania
}

\author{
Biji T Kurien, Tim Gross, R Hal Scofield
}

Barbering (excessive grooming causing hair loss) in mice resembles trichotillomania (uncontrollable hair pulling) in humans in several respects and may be a useful model of trichotillomania, especially for investigating the complex genetic and environmental interactions

Our interest in systemic lupus erythematosus led us to develop an animal model of lupus by immunising rabbits or mice with peptides that are targets of autoimmune sera from people with lupus. Animals immunised with these peptides developed autoimmunity to the entire Ro ribonucleoprotein as well as to other autoantigens..$^{1-3}$ During this study, we observed the loss of facial hair in a group of five experimental mice, possibly a sign of alopecia, a symptom of lupus. When we observed the characteristics of the hair loss and the fact that one of the mice had not lost her facial hair whereas the other four had, we realised that this was a clear case of "barbering."

\section{Barbering in mice}

Fur and whisker trimming by laboratory mice is referred to as "barbering." Laboratory mice housed in groups are frequently found with their facial hair and whiskers removed (figure). In one study facial alopecia was found in three of four adult female Fisher 344 rats that shared a cage for two months. ${ }^{4}$ The hairless areas were non-pruritic and without any association with pathogenic skin bacteria, dermatophytes, or ectoparasites. The authors found that when the unaffected rat was placed with a different set of rats, facial alopecia became evident in those animals within six days, and the hair of the original cagemates grew back within 21 days. Thus the alopecia was found to be caused by a dominant female "barber."

In another study the barbering process was videotaped in pairs of C57BL6 mice containing a dominant barber and a passive recipient, which showed that dominant mice were responsible for barbering the hair of the recipient (the "Dalila effect").
Arthritis and

Immunology Program,

Oklahoma Medical Research Foundation, $825 \mathrm{NE} 13$ th Street, Oklahoma City, OK 73104, USA

Biji T Kurien senior research scientist

Tim Gross senior research assistant

R Hal Scofield associate member Correspondence to: B T Kurien biji-kurien@ omrf.ouhsc.edu

BMJ 2005;331:1503-5 